\title{
SOSIALISASI POTENSI ENERGI TERBARUKAN ANGIN (BAYU) ANTARA UNIVERSITAS MATARAM (UNRAM) BEKERSAMA DENGAN UVERSITAS TEKNOLOGI SUMBAWA (UTS) DI PULAU SUMBAWA
}

\author{
Made Sutha Yadnya1, Teti Zubaidah ${ }^{2}$, Abdullah Zainuddin ${ }^{3}$, Bulkis Kanata $^{4}$, Paniran $^{5}$

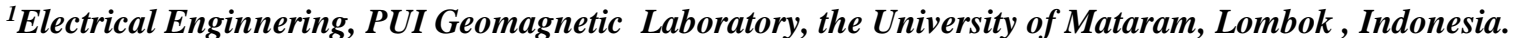 \\ ${ }^{12345}$ Jurusan Teknik Elektro, Fakultas Teknik Universitas Mataram, NTB, Indonesia
}

\section{Article history}

Received: 12 Maret 2019

Revised: 15 Maret 2019

Accepted: 20 Maret 2019

*Corresponding Author:

Made Sutha Yadnya,

Electrical Enginnering, PUI

Geomagnetic Laboratory,

the University of Mataram,

Lombok , Indonesia;

Email: msyadnya@unram.ac.id
Abstract: National Energy Policy, is to increase energy diversification through efforts to use renewable energy such as renewable non-fossil fuels, especially wind energy until 2025. By utilizing renewable energy, the dependence on fossil fuels on the national energy supply system can decrease. Sumbawa Island has the potential for wind energy around $220 \mathrm{KW}$ (assuming each location is built 10 units)

Keywords: energy, wind, renewable.

Abtrak: Kebijakan Energi Nasional, adalah meningkatkan diversifikasi energi melalui upaya pemanfaatan energi terbarukan seperti terbarukan non fosil terutama energi angin (bayu) sampai tahun 2025. Dengan memanfaatkan energi terbarukan ketergantungan penggunaan bahan bakar fosil pada sistem penyediaan energi nasional dapat menurun.. Pulau Sumbawa potensi energi angin sekitar $220 \mathrm{KW}$ (dengan asumsi masing-masing lokasi dibangun 10 unit)

Kata kunci: energi, angin, terbarukan

\section{PENDAHULUAN}

Energi merupakan kekuatan serta ketahanan bagi suatu negara. Indonesia memiliki sejarah energi yang dimulai pada akhir abad ke-19, ketika beberapa perusahaan Belanda mendirikan pembangkit tenaga listrik untuk keperluan sendiri. Pengusahaan tenaga listrik tersebut berkembang menjadi untuk kepentingan umum, diawali dengan perusahaan swasta Belanda yaitu NV. Kincir angin yang pertama dibangun pada masa pemerintahan. Kincir angin kuno itu memiliki 8 sirip yang berputar secara vertical mirip putaran gasing. Fungsi kincir angin untuk menggiling jagung, gandum, tebu, serta memompa air. Lalu Kincir angin digunakan kembali untuk membangkitkan listrik dibangun di Denmark diahir abad ke-19. Setelah perang dunia (PD I), layar dengan penampang melintang menyerupai sudut propeler pesawat sekarang disebut kincir angin type propeler' atau turbin. Untuk cuaca ekstrim yang terjadi di Indonesia sering terjadi namun dapat diatasi dengan memgklasifikasikan yang stabil (stasioner) dan non sttabil (non stasioner) Yadnya (2008).

Pada jaman kemerdekaan salah satu langkah awal yang pemerintah lakukan adalah dengan membuat blueprint Pengelolaan Energi Nasional 2006 - 2025 (Keputusan Presiden RI nomer 5 tahun 2006). Secara garis besar, dalam blueprint tersebut ada dua macam solusi yang dilakukan secara bertahap hingga tahun 2025, yaitu peningkatan efisiensi penggunaan energi (penghematan) dan pemanfaatan sumber-sumber energi baru (diversifikasi energi). Mengingat rasio elektrifikasi yang masih relatif rendah, yaitu $63 \%$ pada tahun 2005, sedangkan Indonesia menargetkan rasio elektrifikasi 
$95 \%$ pada tahun 2025. Tenaga listrik kini merupakan landasan bagi kehidupan modern, dan tersedianya dalam jumlah dan mutu yang cukup menjadi syarat bagi suatu masyarakat yang memiliki taraf kehidupan yang baik dan perkembangan industri yang maju. Dalam merencanakan suatu sistem penyediaan tenaga listrik, lokasi fisik pusat tenaga listrik, saluran transmisi dan gardu induk perlu ditentukan dengan tepat, agar dapat diperoleh suatu sistem yang baik, ekonomis dan dapat diterima masyarakat. Berikut adalah skematis Prinsip Penyediaan Tenaga Listrik Casindo(2011).

Sosialisasi potensi PLTB di daerah Pulau Sumbawa untuk ketersediaan energi listrik di NTB belum sepenuhnya merata, khususnya bagi warga yang kurang mampu dan tinggal di atas perbukitan. Kondisi jalan yang gelap gulita di malam hari menyebabkan tingginya tingkat kriminalitas dan kurang optimalnya jam belajar siswa di rumah. Sebuah kincir angin berkapasitas $1000 \mathrm{Wp}$ (Hibah dari KemenRistek) telah dipasang dan akan dimanfaatkan untuk memenuhi kebutuhan penerangan serta menjalankan pompa air di sumur umum warga. Ini perlu disosialisasi bahwa sebenarnya NTB mempunyai potensi PLTB yang baik, serta cukup berlimpah agin yang melintas pada daerah NTB.

\section{METODE}

Dalam Kebijakan Energi Nasional, salah satu kebijakan utama pengembangan energi nasional adalah meningkatkan diversifikasi energi melalui upaya pemanfaatan energi terbarukan seperti panas bumi, tenaga air, energi surya, energi angin dan biomassa minimal sebesar $17 \%$ dari total energy mix pada tahun 2025. Dengan memanfaatkan energi terbarukan ketergan tungan penggunaan bahan bakar fosil pada sistem penyediaan energi nasional dapat menurun. Selain itu, isu pemanasan global yang dikaitkan dengan konsumsi bahan bakar fosil menjadi salah satu alasan untuk mengurangi tingkat penggunaan bahan bakar fosil.Mengingat peran energy terbarukan yang sangat penting dalam system penyediaan energi nasional, diperlukan kebijakan yang mendukung keberlanjutan pelaksanaannya Casindo (2010).

Tampilan citra satelit Himawari, satelit yang memberikan infornasi angin utamanaya pada daerah Nusa Tenggara Barat dapat dilihat pada gambar 1. Adapun Derah Pulau Sumbawa mempunyai karakteristik dengan arah timur-barat dan ada beberapa lembah yang berarah utama timur laut - barat daya dan bara tlaut - tenggara. Di Teluk Saleh merupakan lekuk terbesar potensial terhadap energi terbarukan agin (bayu) Pulau Sumbawa ini menjadi dua bagian, yaitu Sumbawa Barat dan Timur. Bagian utara pulau terdiri atas jalur gunungapi Kuarter dengan puncak tertinggi $2851 \mathrm{~m}$ yakni Gunung Tambora. Bagian selatan terdiri dari punggungan-punggungan yang kasar dan tidak beraturan, tersayat oleh sistem perlembahan berarah utama timur laut - barat daya. Ketinggian perbukitan berkisar antara $800-1400 \mathrm{~m}$ di atas permukaan laut. Lugra (2003).

Untuk melaksankan sosilisasi dalam rangka menjalankan Tri Dharma Perguruan Tinggi yakni pengabdian, maka kecil Tim PUI membagikan pengalamana dalam pemasangan tower kincir angin dan pemanfaatan yang telalah dapat dipergunakan di Desa Sade, Rembitan, Lombok Tengah yang berdekatan dengan Observatorium milik Universitas Mataram. Pemasangan turbin tersebut pada tahun 2016 menggunakan Hibah Iptek Bagi Mayarakat Zubaidah et all(2017).

Contoh pemasangan turbin dapat dilihat pada gambar. 2 yang telah dilaksanakan. PUI Geomagnetikyang cikal bakalnya dari Lombok Observatorium yang meneliti tentang anomaly magnet bumi sebagi precursor gempa. Pengurusnya merupakan sebagian besar dari Dosen Jurusan Teknik Elektro Universitas Mataram. PUI mempunyai data serta analisis data untuk informasi yang berintegrasi dengan BMKG, Lapan, GFZ, secara mendunia Zubaidah et all(2018). 


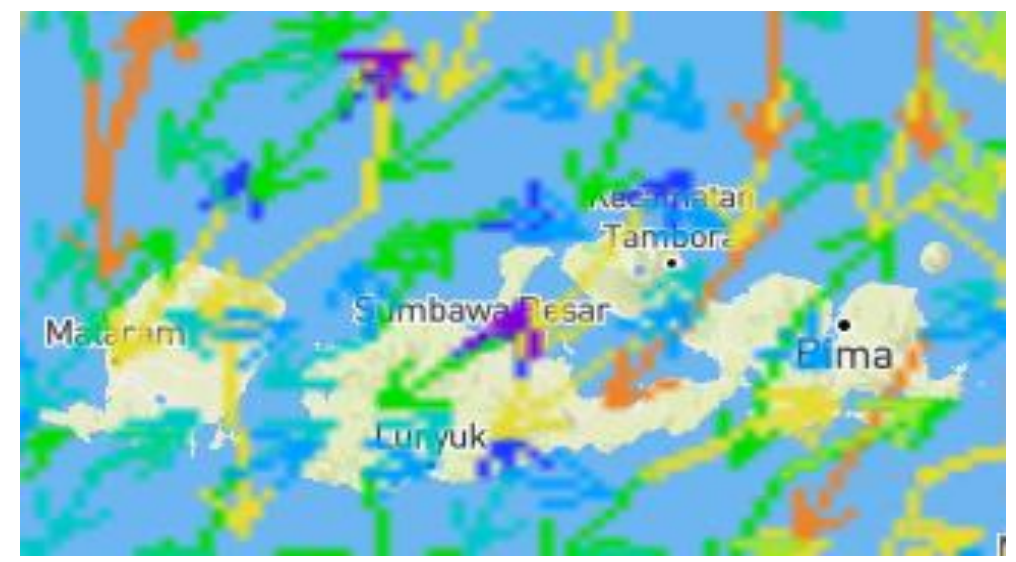

Gambar. 1 Cirta Satelit Potensi Angin Nusa Tenggara Barat 2018

\section{HASIL DAN PEMBAHASAN}

Perjalanan ke Sumbawa memakan waktu 2 hari serta transportasi yang cukup lama. Dari Mataram ke Pelabuhan Kayangan 3 jam, serta dari Pototano ke Sumbawa Besar 2 jam. Ternyata Universitas Teknologi Sumbawa (UTS) berada di hutan yang sangat asri dan mempunyai nilai edukasi yang tinggi. Potensi sangat besar untuk pengembangan energi alternate. Namun semua itu akan hilang apabila terjadi bencana gempa bumi. Adapun bahaya yang mengancam ini pertu di mitigasi dengan baik. Potensi energi bumi dengan lempeng yang bergerak menyebabkan terjadinya gempa. Sosialisasi kegempaan yang dilakukan.

Dari hasil studi pemetaan angin yang akan disimulasikan dipasang di Pulau Sumbawa mengacu dari hasil yang telah dilakukan di Pulau Lombok terdapat potensi energi angin kurang lebih $60 \mathrm{KW}$ (dengan asumsi masing-masing lokasi dibangun 10 unit), sedangkan Pulau Sumbawa potensi energi angin sekitar $220 \mathrm{KW}$ (dengan asumsi masing-masing lokasi dibangun 10 unit) lokasi yang berbeda. Pengabdian ini mengingatkan bahwa ada potensi angin di Pulau Sumbawa yang belum termanfaatkan. Potensi ini baru terelisasi apabila ada investor baik dalam maupun luar negeri yamg mau menanamkan modal dan sebagai institusi perguruan tinggi bekerjasama antara Universitas Mataram dan Universitas Teknlologi Sumbawa.

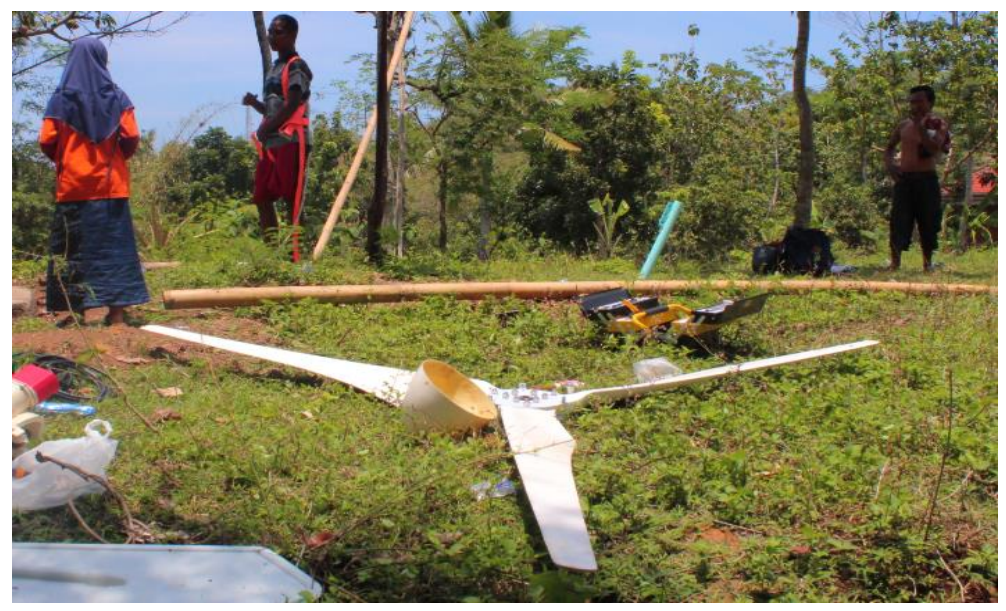

Gambar 2 Pemasangan Turbin 
Pelaksanaan dilaksanakan langsung di Universitas Teknologi Sumbawa di Pulau Sumbawa dengan dengan dilengkapai peningkatan kemampuan dari masing-masing individu dan perancangan survai:

$\checkmark$ Diskusi dengan warga dan tokoh masyarakat.

$\checkmark$ Survey lokasi dan pemilihan lokasi kegiatan bersama masyarakat setempat. Pengukuran kecepatan angin dan energi listrik yang dihasilkan.

$\checkmark$ Penyiapan alat dan bahan, serta pengujian di Lab. EBT.

$\checkmark$ Analisa generator yang akan digunakan di lokasi, merencananak instalasi listrik dari turbin angin sampai ke beban.

$\checkmark$ Sosialisasi penggunaan dan perawatan fasilitas pembangkit listrik tenaga angin bagi warga di sekitar lokasi. Monitoring dan evaluasi (administratif dan di lokasi) dapat dilihat pada gambar. 3 dan gambar. 4 .

$\checkmark$ Publikasi hasil-hasil pengabdian masyarakat

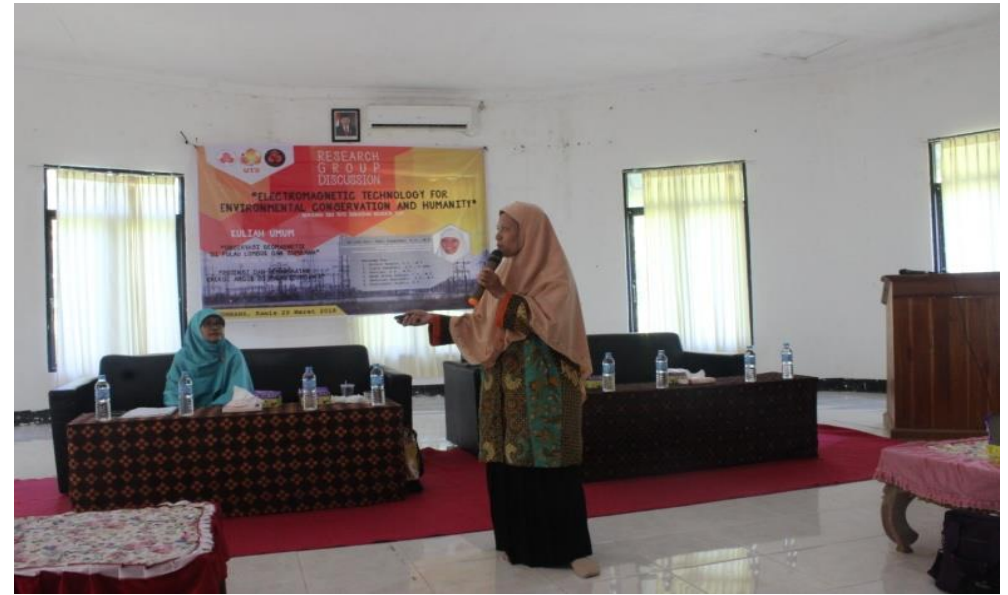

Gambar 3. Teti Zubaidah sedang Sosialisasi Energi Angin (Bayu)

Gambar 3 menjelaskan bahwa ada potensi angin(bayu yang belum dieksekusi di Pulau Sumbawa dengan menampilkan data data yang tersedia. Pada Gambar 4 peserta dan pembicara dengan menampilkan software untuk menghitung potensi angin pada setiap titik tujuan, Tujuan yang dihitung barulah posisi kincir di tepi pantai (garis pantai)

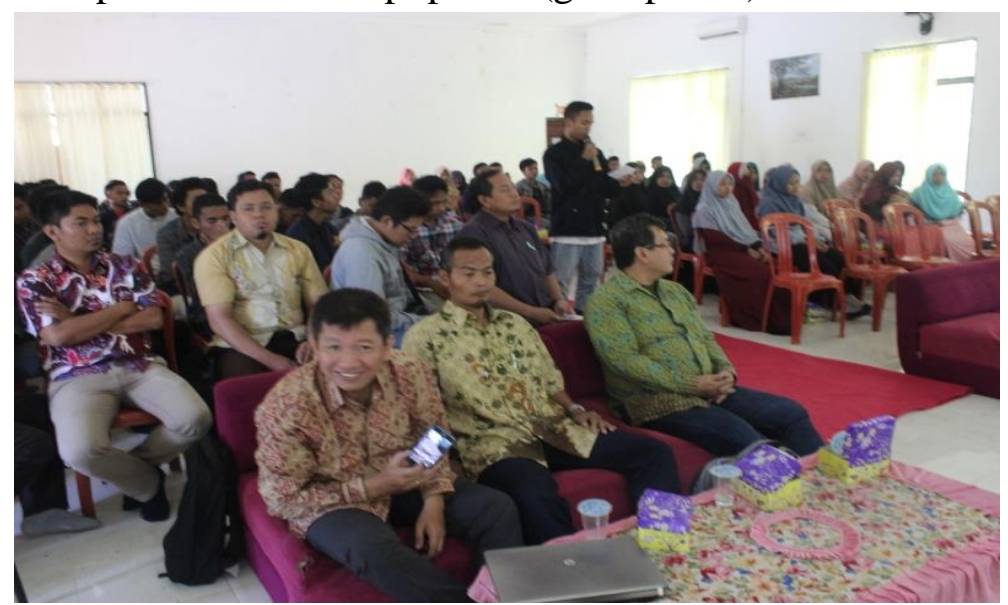

Gambar. 4 Peserta Sosialisasi Angin di Universitas Teknologi Sumbawa. 


\section{KESIMPULAN}

Setelah melaksanakan pengabdian di Universitas Teknologi Sumbawa (UTS) khusus pada Jurusan Teknik Elektro, memberikan gambaran dan UTS dan Universitas Mataram (Unram) siap membantu jika ada pekerjaan dan instalasi pemasangan tower dan turbin pembangkit listrik tenaga agin (bayu0 di Pulau Sumbawa oleh Pemerintah Pusat atau Daerah, ataupun lembangan non pemerintahan untuk menambah daya catuan di Pulau Sumbawa yang saat ini masih mengandalkan enrgi fosil.

Enirgi terbarukan dengan memanfaatkan agin (bayu0 yang perlu diperhatikan asupan angin yang konstan dan baterai yang dipakai menyimpan dilihat umur atau waktu (life time). Dalam invertasi energi terbarukan membutuhkan bianya yang cukup besar dan pemeliharaan yang effektif serta effisien.

\section{Ucapan Terima Kasih}

Terima kasih diucapkan kepada PUI Geomagnetik Dosen, Laboran, Asisten dan Mahasiswa Jurusan Teknik Elektro Universitas yang telah membantu dan menfasilitasi dalam menyelesaikan makalah ini. Pembiayaan untuk publikasi ini sepenuhnya menggunakan dana mandiri yang dikumpukan dari setoran setiap anggota Pengabdian pada Masyarakat. Semoga makalah ini dapat inspirassi dari kegiatan-kegiatan selanjutnya.

\section{DAFTAR PUSTAKA}

Casindo (2011) 'Rencana Aksi Energi Terbarukan Provinsi Nusa Tenggara Barat Tahun 20102025' Laporan Jurnal Agustus 2011 D-25

Lugra I.W, Wahib A., Zuraida R., (2003) Peluang Pengembangan Wilayah Pesisir Pantai Sumbawa Barat, Nusa Tenggara Barat Ditinjau dari Aspek Karakteristik dan Gejala Perubahan Garis Pantai Jurnal Geologi Kelautan, vol. 1, no. 2, September $2003: 1-12$. Yadnya M.S.,(2008), “Akaike Information Criteria Application to Stationary and

Nonstationary Rainfalls for Wireless Communication Channel in Surabaya” 1858-

1633 , ICTS 2008 Surabaya

Zubaidah T., Kanata B., Yadnya M.S.,(2017) “Engaging Community in Develoving Elektrical Wind Power in Rembitan Village Central Lombok”. International Conference QiR University of Indonesia volume 1.

Zubaidah T.., Kanata B.., Yadnya M.S., Riskia S., (2018) “Earth Magnetic Fields Evolution over Nusa Tenggara Region from Declination and Inclination Changes on Lombok Geomagnetic Observatory”. International Conference AEMT, IEEE Explore : 2018 2nd International Conference on Applied Electromagnetic Technology. 